\title{
Pozitronų emisijos tomografija - ką svarbu prisiminti
}

\author{
Laima Tamkevičiūtè, Jurgita Zaveckienė, Nemira Jurkienė \\ LSMU MA Radiologijos klinika
}

Reikšminiai žodžiai: PET, ${ }^{18} \mathrm{~F}-\mathrm{FDG}$, tyrimo įvertinimas.

Santrauka. Pozitronų emisijos tomografija (PET) - pasaulyje plačiai paplitęs ir klinikinèje praktikoje įsitvirtinęs, o Lietuvoje vis dar naujas neinvazinis branduolinės medicinos radiologinis tyrimas, kurio panaudojimas pulmonologijoje susijęs su vėžio diagnostika, jo išplitimo ir ligos eigos įvertinimu. Kitaip nei daugelis kitų radiologinių vaizdinių tyrimų, kurie padeda j̇vertinti tik morfologinius organų ir audinių pokyčius, PET su ${ }^{18}$ F-FDG padeda nustatyti audinių funkcinius metabolinius pokyčius in vivo. Daug gliukozės metabolizmą veikiančių veiksnių gali lemti santykinai mažesnį PET su ${ }^{18} \mathrm{~F}-\mathrm{FDG}$ specifiškumą, todèl norint tinkamai interpretuoti tyrimo rezultatus būtina gerai ǰvertinti klinikinius ir anamnezès duomenis. Šio tyrimo diagnostinè vertè labai priklauso nuo tinkamo pacientų paruošimo. PET gali keisti ligos vadybą, tačiau negali pakeisti kitų radiologinių, instrumentinių ir histologinių tyrimų.

Pozitronų emisijos tomografija (PET) - pasaulyje plačiai paplitęs ir klinikinéje praktikoje ịsitvirtinęs, o Lietuvoje vis dar naujas, nuo 2012 metu atliekamas neinvazinis branduolinès medicinos radiologinis tyrimas. Kitaip nei daugelis kitų radiologiniu vaizdinių tyrimų, kurie padeda įvertinti tik struktūrinius morfologinius organų ir audinių pokyčius, PET naudojant ivairius radiofarmacinius preparatus (RFP) (1 lentelè) padeda nustatyti audinių metabolinius ir funkcinius pokyčius in vivo [1, 2]. Šio tyrimo metu pacientui i veną sušvirkščiama biologiškai aktyvios medžiagos, kuri patenka i organizmo ląsteles ar jų membranas ir dalyvauja organizme atliekant tam tikrą funkciją ar vykstant cheminei reakcijai [2]. Šios biologiškai aktyvios medžiagos būna žymètos radioaktyviais izotopais (pvz.: ${ }^{18} \mathrm{~F},{ }^{11} \mathrm{C},{ }^{13} \mathrm{~N},{ }^{15} \mathrm{O}$ ir kt.), kurie yra nestabilūs, greitai skyla atiduodami pozitronus ir energiją, kuri fiksuojama ir objektyvizuojama PET įrenginiais - kur RFP susikaupia daugiau, fiksuojamas švytejjimas, sukuriamas objektyvus vaizdinis tyrimo ivertinimas. RFP susitelkimo intensyvumas objektyvizuojant išreiškiamas standartizuota kaupiamąja reikšme SUV (angl. standard uptake value).
Kai kurių struktūrų SUV pateikiamos 2 lentelèje.

PET indikacijos grindžiamos galimybe nustatyti fiziologiniu metabolinių procesuc pokyčius. Plačiausiai šis metodas taikomas onkologijoje (naviko diferenciacijai, išplitimo ịvertinimui ir ligos stadijavimui, gydymo efektyvumo stebėsenai, likutinio audinio gyvybingumo nustatymui, atkryčio nustatymui, optimalios biopsijos vietos ir spindulinio gydymo planavimui ir kt.), kardiologijoje (miokardo gyvybingumo ir metabolizmo ịvertinimui ir kt.), neurologijoje (demencijų diagnostikai), reumatologijoje (vaskulitai ir kt.) [3-5]. Kadangi PET anatominis informatyvumas menkas, nustatomų pokyčių ir galimų fiziologiniu veiksnių diferenciacijai, ju lokalizacijos įvertinimui būtina papildoma morfologinė informacija [6]. Ji galima vizualiai derinant PET duomenis su atliktu kompiuterinès tomografijos (KT), rečiau - magnetinio rezonanso tomografijos (MRT) tyrimu vaizdais, šių tyrimų vaizdus suliejant pasitelkus programinę įrangą ar atliekant kombinuotus PET-KT (PET-MRT) tyrimus. Lietuvoje PET-KT tyrimai atliekami pagal Sveikatos apsaugos ministro ịsakymu Nr. V-448 patvirtintą indikaciju sąrašą (3 lentelè) [7]. Pulmonologinių indikacijų aktualumą patvirtina gau-

\begin{tabular}{|c|c|c|c|}
\hline Preparatas & Pritaikymas & Preparatas & Pritaikymas \\
\hline${ }^{11} \mathrm{C}$-metioninas & $\begin{array}{l}\text { Glioma } \\
\text { Prieskydinių liaukų } \\
\text { navikai }\end{array}$ & $\begin{array}{l}{ }^{18} \text { F-fluoro } \\
\text { DOPA }\end{array}$ & $\begin{array}{l}\text { Igimtas hiperinsuli- } \\
\text { nizmas } \\
\text { Parkinsono liga } \\
\text { Neuroendokrininiai } \\
\text { navikai }\end{array}$ \\
\hline $\begin{array}{l}{ }^{13} \mathrm{~N} \text {-amonio-chloridas, } \\
{ }^{13} \mathrm{Rb} \text {-rubidžio-chloridas }\end{array}$ & $\begin{array}{l}\text { Miokardo perfuzijos } \\
\text { vertinimas }\end{array}$ & ${ }^{18} \mathrm{~F}$-fluoridas & $\begin{array}{l}\text { Gerybinès ir piktybi- } \\
\text { nės kaulų ligos }\end{array}$ \\
\hline $\begin{array}{l}{ }^{11} \mathrm{C} \text {-cholinas ir } \\
{ }^{18} \mathrm{~F} \text {-fluorocholinas }\end{array}$ & $\begin{array}{l}\text { Prostatos karcinoma } \\
\text { Kepenų ląstelių karcinoma }\end{array}$ & $\begin{array}{l}{ }^{18} \mathrm{~F} \text {-florbetapir } \\
(\text { Amyvid })\end{array}$ & Alzhaimerio liga \\
\hline${ }^{11} \mathrm{C}$-acetatas & $\begin{array}{l}\text { Kepenų ląstelių karcinoma } \\
\text { Prostatos } \\
\text { karcinoma }\end{array}$ & $\begin{array}{l}{ }^{18} \mathrm{~F}-{ }^{16} \beta \text {-fluoro-5- } \\
\text { dihidrotes- } \\
\text { tosteronas } \\
\text { (FDHT) }\end{array}$ & Prostatos karcinoma \\
\hline $\begin{array}{l}{ }^{68} \mathrm{Ga} \text { galiu žymèti soma- } \\
\text { tostatino receptoriai }\end{array}$ & $\begin{array}{l}\text { Neuroendokrininiai } \\
\text { navikai }\end{array}$ & & \\
\hline
\end{tabular}


2 lentelè. Standartizuota ${ }^{18} \mathrm{~F}-\mathrm{FDG}$ kaupiamoji reikšmè

\begin{tabular}{ll}
\hline Smegenys & $3-10$ \\
\hline Plaučiai & 0,5 \\
\hline Tarpuplautis & $1,5-2,5$ \\
\hline Širdis & $0,5-5,0$ \\
\hline Raumenys & 1,0 \\
\hline Kepenys & 3,5 \\
\hline Blužnis & 1,9 \\
\hline Šlapimo pūslè & $30-60$ \\
\hline
\end{tabular}

sūs literatūros šaltiniai. Pavyzdžiui, Goud ir bendr. metaanalizès duomenimis, diferencijuojant piktybinius ir nepiktybinius plaučių darinius PET jautrumas siekia 96,8 proc., o specifiškumas $-77,8$ proc., ribiniu FDG telkimosi kriterijumi laikoma 2,0-2,5 SUV [8, 9]. Tiriant metastazes tarpuplautyje, PET yra labiau jautrus nei specifiškas, kai KT matomi padideję limfmazgiai (jautrumas - 100 proc., specifiškumas - 78 proc.), bet labiau specifiškas nei jautrus, kai jie nepadidèję (atitinkamai 82 proc., ir 93 proc.) [10, 11].

Svarbu pabrèžti, jog šio tyrimo diagnostinè vertė ir praktinis pritaikymas labai priklauso nuo naudojamo RPF rūšies ir fizikinių savybių. Biologiškai aktyvios medžiagos žymėjimas radioaktyviais izotopais yra sudètingas procesas, kuris vyksta prietaise, vadinamame ciklotronu. Dèl didelio izotopų nestabilumo (greito jų skilimo), neturint ciklotrono, dèl transportavimo laiko sąnaudų PET tyrimai gali būti atliekami naudojant tik gana stabiliais izotopais žymėtas medžiagas - šiuo atžvilgiu tinkamas radioaktyvaus fluoro ${ }^{18} \mathrm{~F}$ izotopas, kurio pusinès eliminacijos laikas 110 minučių. Kokybiškam tyrimui atlikti ir įvertinti būtina, kad tiriamajam būtų sušvirkštas pakankamas individualiai apskaičiuojamas radioaktyviųjų dalelių skaičius, kuris fiksuotame tūrio vienete dèl medžiagos nestabilumo gali ženkliai skirtis. Šiuo metu Lietuvoje PET-KT tyrimai atliekami dviejuose centruose naudojant transportuojamą ${ }^{18} \mathrm{~F}$ žymètą gliukozès analogą. Todèl laiko veiksnys itin svarbaus organizuojant visą pacientų paruošimo ir PET tyrimų procesą.

\section{${ }^{18}$ F-FDG}

Klinikinejje praktikoje dažniausiai naudojamas RFP yra jau minètas nefiziologinis gliukozès analogas, prie kurio prijungtas radioaktyvus fluor-2-deoksi-2-[18]fluor-D gliukozè ( $\left.{ }^{18} \mathrm{~F}-\mathrm{FDG}\right)$. Preparato paplitimas susijęs tiek su izotopo savybėmis (santykinai ilgesnis pusinès eliminacijos laikas, mažiausia $(0,25 \mathrm{MeV})$ pozitronų energija, didesnė gaunamų vaizdụ rezoliucija), tiek su gliukozès vieta ląstelių metabolizme.

FDG, kaip ir gliukozè, ì ląstelę patenka per gliukozès nešiklius, iš kurių svarbiausi yra GLUT1 (angl. glucose transporter 1), jie yra beveik visose ląstelès, nejautrūs insulinui, ir GLUT4, esantys riebaliniame audinyje, širdies ir skersaruožių raumenų ląstelèse, jautrūs insulinui. Ląstelèje FDG, kaip ir gliukozè, yra fosforilinama dalyvaujant heksokinazei, susidaro FDG-6-fosfas (FDG-6-F), kuris negali būti toliau metabolizuojamas ir kaupiasi ląsteleje (1 pav.). Tarpląstelinèje terpèje esanti FDG sntykinai greitai pasišalina, o ląstelèse susikaupęs FDG-6-F lieka. Taigi, PET su
3 lentelè. PET-KT tyrimo indikacijos pulmonologijoje [7]

Planuojant radikalų gydymą

Ligos atkryčiui nustatyti po taikyto gydymo, kai KT tyrimas nepakankamai informatyvi

Pavienis (solitarinis) darinys plautyje nuo $1 \mathrm{~cm}$ iki $3 \mathrm{~cm}$ dydžio esant vidutinei (5-60 proc.) piktybiškumo tikimybei ir nesant mor fologinio darinio patvirtinimo prieš numatomus invazinius tyrimus ir (ar) radikalų chirurginị gydymą

Prieš numatomą radikalų pirminio ar lokaliai atsinaujinusio plaučių vėžio spindulinị gydymą švitinimo tūriui optimizuoti

4 lentelè. Fiziologinis FDG kaupimasis [17-22]

\begin{tabular}{ll}
\hline Fiziologinis FDG kaupimas & \\
\hline Skeleto ir lygieji raumenys & Užkrūčio liauka \\
\hline Širdies raumuo & Krūtis laktacijos metu \\
\hline Smegenys & Areolè \\
\hline $\begin{array}{l}\text { Seilių liaukos ir limfinis audi- } \\
\text { nys kakle ir galvoje }\end{array}$ & $\begin{array}{l}\text { Moteriškiieji lyties organai (gimda } \\
\text { menstruacijų metu, gimda ir } \\
\text { kiaušidès ovuliacijos metu, corpus } \\
\text { luteum cista) }\end{array}$ \\
\hline Skydliaukė & Šlapimo organų sistema \\
\hline Rudieji riebalai & Virškinimo traktas \\
\hline
\end{tabular}

${ }^{18} \mathrm{~F}-\mathrm{FDG}$ nustatomos vietos organizme, kur yra padidèjęs gliukozès suvartojimas. Dar XX a. pradžioje Nobelio premijos laureatas Warburg su bendraautoriaus nustatè, kad navikinès ląstelès metabolizmui sunaudoja daugiau gliukozès nei sveikų audinių ląstelès [12]. Taip yra todèl, kad navikinèse ląstelèse padidejjęs heksokinazès aktyvumas [13, 14] ir aktyvinama gerokai daugiau GLUT-1 nešiklių [15].

Tačiau, kaip žinia, gliukozès metabolizmas gali pagreitèti dèl ịvairių priežasčių: ne tik dèl onkologinių ligų, bet ir ịvairių nepiktybinių darinių, hipoksijos, infekcijos, fiziologinių priežasčių ir kt. (2 pav.). Dèl to FDG-PET yra jautrus, bet mažesnio specifiškumo tyrimas $[8,16]$. Kai kurių organų ir audinių gliukozès poreikis didelis ir labai priklauso nuo jų funkcinès būklès (4 lentelè) [17 -22]. Gliukozès metabolizmas iqvairiuose organuose ir audiniuose gali suaktyvèti dèl ịvairių organizme vykstančių fiziologinių procesų. Pavyzdžiui, FDG susikaupimas šlapimo organų sistemoje dažniausiai nèra susijęs su didesniu gliukozès poreikiu - FDG šalinama per inkstus ir šlapimo pūslëje susidaro rezervuaras.

\section{PACIENTŲ PARUOŠIMAS}

Visiškai išvengti foninio FDG telkimosi neįmanoma, norint maksimaliai padidinti tyrimo jautrumą, tai yra metabolinio aktyvumo skirtumo nustatymą, svarbu suprasti organizme vykstančią gliukozės apykaitą ir jos pokyčius ịvairių būkliu bei ligu atveju. Taigi akivaizdu, jog gliukozès metabolizmo sutrikimai ir būklès (hiperglikemija, cukrinis diabetas, uždegimo ligos, reparacijos procesai ir kt.) bei jau aptarti jas veikiantys vidiniai bei išoriniai veiksniai gali reikšmingai sumažinti tyrimo diagnostinę vertę. Todèl, siekiant padidinti tyrimo specifiškumą ir sumažinti klaidingos gautu rezultatų interpretacijos tikimybę, būtinas tinkamas paciento 
paruošimas bei išsamūs klinikiniai ir anamnezès duomenys [23, 24]. Didelè dalis svarbiuc pacientuc atrankos ir siuntimo atlikti PET-KT aspektu aptariama gydymo isstaigu patvirtintuose siuntimo ir rezultatu pateikimo aprašuose bei pacientams pateikiamose atmintinėse [25].

Labai svarbi paciento paruošimo tyrimui dalis - sumažinti FDG kaupimąsi skersaruožiuose raumenyse. Pacientui 24 valandas iki tyrimo negalima daryti masažo procedūrų, užsiimti aktyvia veikla, o 6 val. prieš tyrimą - jokia jam neiprasta fizine veikla (pavyzdžiui, bėgti, greitai eiti). Todèl gydytojas turètuc patarti, kaip susiplanuoti laiką, kad jo pakaktų laiku atvykti. Prieš tyrimą ir jo metu pacientas negali būti sušalęs, tyrimui skirta patalpa turi būti šilta. Nuo atvykimo iki tyrimo pacientas 30-60 min. turètuc praleisti šiltoje aplinkoje. Pacientas tyrimo metu negali kalbèti, kramtyti gumos, labai svarbu, kad pacientas gulètu patogiai. Diskomfortas ir itampa gali paskatinti FDG kaupimąsi kaklo ir nugaros raumenyse, kalbant padideja FDG kaupimasis gerklų raumenyse, drebulio, kramtymosi metu raumenyse taip pat metabolizuojama daugiau gliukozès. Visos minètos priemonès sumažina foninị FDG kaupimąsi skersaruožiuose raumenyse.

Tyrimo metu labai daug FDG susitelkia šlapimo pūsleje, o tai gali labai trukdyti įvertinti pokyčius, jei tiriama patologija yra mažajame dubenyje. Norint sumažinti FDG koncentraciją šlapime, labai svarbu prieš tyrimą per dvi valandas išgerti bent litrą vandens. Suvartotas pakankamas skysčių kiekis pagerina tyrimo vertinimą ir padeda patikimiau ištirti mažąji dubenị. Labai svarbu, kad skysčiuose nebūtų angliavandenių, negalima gerti sulčių, kavos ir kitų gèrimų, turinčių kofeino ar kitų simpatinę nervų sistemą aktyvinančių medžiagų, kad nesuaktyvètų foninis FDG telkimasis [23, 24].

Hiperglikemija - viena svarbiausiuc tiesioginę įtaką tyrimo rezultatams darančių būklių (3 pav.). Ji galima dèl prisivalgymo prieš tyrimą arba cukrinio diabeto. Esant hiperglikemijai, FDG ir gliukozė konkuruoja dèl patekimo ì ląstelę per gliukozès nešiklius (4 pav.). Tokiu atveju patologiniame židinyje susikaupia mažiau FDG ir rezultatai gali būti klaidingai neigia-

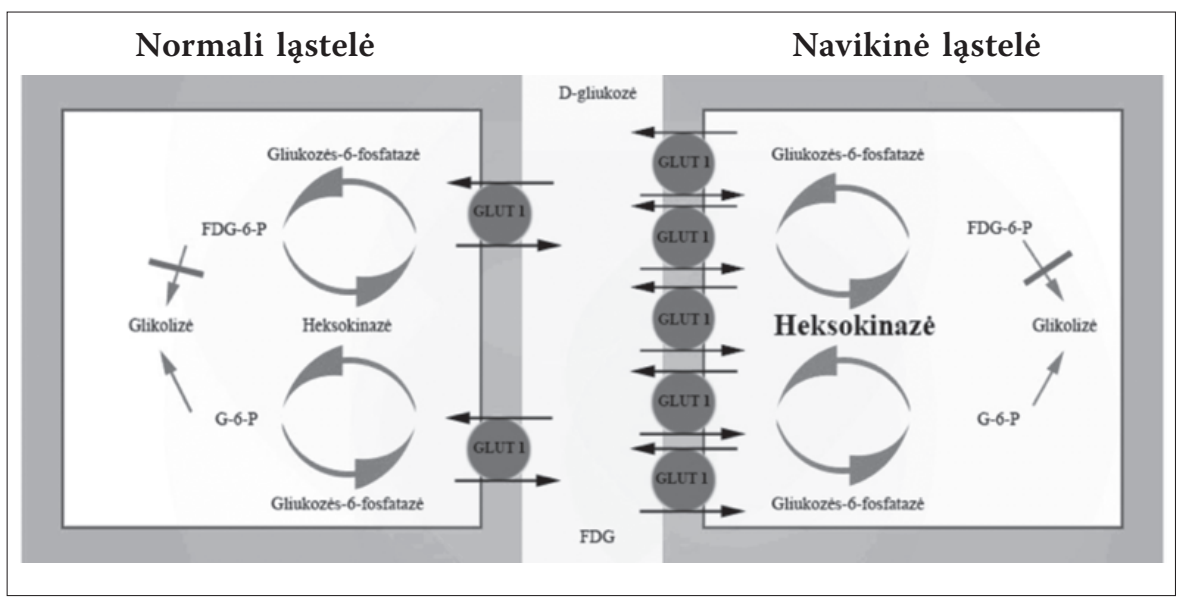

1 pav. Normalių ir navikinių ląstelių gliukozès ir FDG metabolizmas

mi. Norint padidinti jautrumą ir sumažinti klaidingai neigiamų rezultatuc tikimybę, svarbu, kad pacientas nieko nevalgytų 6 valandas prieš tyrimą. Jei tyrimas atliekamas ryte, pacientas turètų nevalgyti po vidurnakčio, o vakarienei valgyti lengvą maistą ir negerti alkoholio. Jei tyrimas planuojamas popiet, pacientas gali valgyti lengvus pusryčius, nevartoti cukrų. Intraveniniai skysčiai, turintys gliukozès ar dekstrozès, bei parenterinis maitinimas taip pat turi būti nutrauktas bent 4 val. prieš tyrimą. Esant normoglikemijai, sumažeja insulino koncentracija kraujo plazmoje, nestimuliuojami riebaliniame audinyje, miokarde, skersaruožių raumenų skaidulose esantys GLUT4 gliukozès nešikliai - taip sumažeja FDG foninis telkimasis riebaliniame audinyje, skersaruožiuose raumenyse bei miokarde ir lengviau ivertinti raumenis, tarpuplauti, naviko metastazes limfmazgiuose.

\section{FDG-PET IR CUKRINIS DIABETAS}

Jeigu pacientas serga cukriniu diabetu (CD), atlikti ir ívertinti FDG-PET tyrimą gali būti sudètinga, todèl paruošimas itin svarbus ir turi būti detaliai aptariamas gydytoju komisijoje PET pagrịstumui įvertinti, suderinant paruošimo būdą su tyrimo laiku [23, 26]. Jei glikemija reguliuojama trumpai veikiančiu insulinu, rekomenduojama pusryčius valgyti 6-7 val., susileisti iprastinę insulino dozę, vẻliau gerti tik nustatytą vandens kiekị, o tyrimo laiką planuoti $12-13$ val. Pacientai, naudojantys insulino pompas, turi būti tiriami 8 val., paliekant pompą nakties režimu, o pusryčiai valgomi po PET tyrimo. Prieš tyrimą pacientas negali nieko valgyti. Būtina sureguliuoti glikemiją prieš tyrimą, nes hiperglikemijos atveju gliukozè konkuruoja su FDG ir šiose ląstelèse susikaupia mažiau. Čia svarbus paciento ir gydančiojo gydytojo bendradarbiavimas. Reikia užtikrinti ne tik normoglikemiją, bet ir mažą insulino koncentraciją - tai padeda išvengti didelio foninio telkimosi. 2 tipo CD sergantys pacientai visus vaistus vartoja iprasta, užgerdami vandeniu. Jei įtariamas virškinimo trakto navikas ar buvo padidejęs FDG kaupimasis ankstesniu PET tyrimu metu, metformino vartojimas nutraukiamas 2 dienas prieš tyrimą (5 pav.).

Net esant normoglikemijai, prieš pat PET tyrimą ištiriama gliukozès koncentracija kraujo serume. Jei glikemija viršija 7,0 mmol/l, tyrimas turi būti atidètas.

\section{KLAIDINGAI TEIGIAMI PET REZULTATAI}

Kaip minèta, net ir tinkamai paruošus pacientą, fiziologiniai procesai gali sąlygoti netolygu ar padidejusi FDG telkimąsi, kuris gali būti interpretuotas kaip patologinis. Gimdoje ir kiaušidèse FDG telkiasi priklausomai nuo menstruacinio ciklo fazès, daugiau ovuliacijos metu, be to, gimdoje galimas padidèjęs telkimasis po abrazijos, endometriumo polipu ar fibroidu atvejais. Menopauzès tarpsnio moterys, jei FDG telkiasi gimdoje ar 


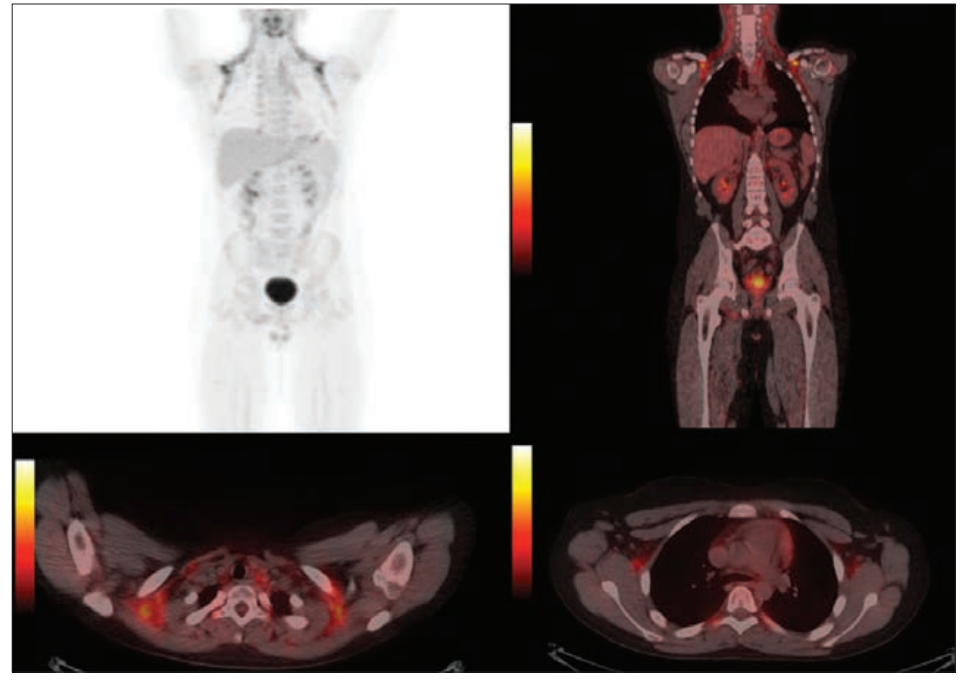

2 pav. PET-KT su ${ }^{18}$ F-FDG: padidèjęs FDG telkimasis ruduosiuose riebaluose; ryški FDG sankaupa šlapimo pūslèje

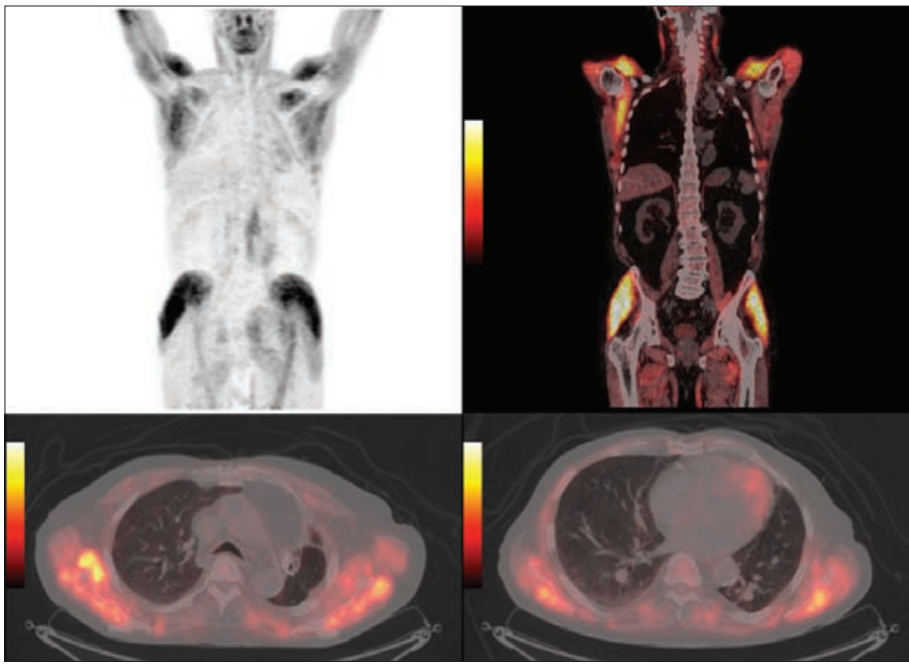

3 pav. PET-KT su ${ }^{18}$ F-FDG: ryškus foninis FDG telkimasis prieš tyrimą pavalgiusio paciento skersaruožiuose raumenyse, miokarde

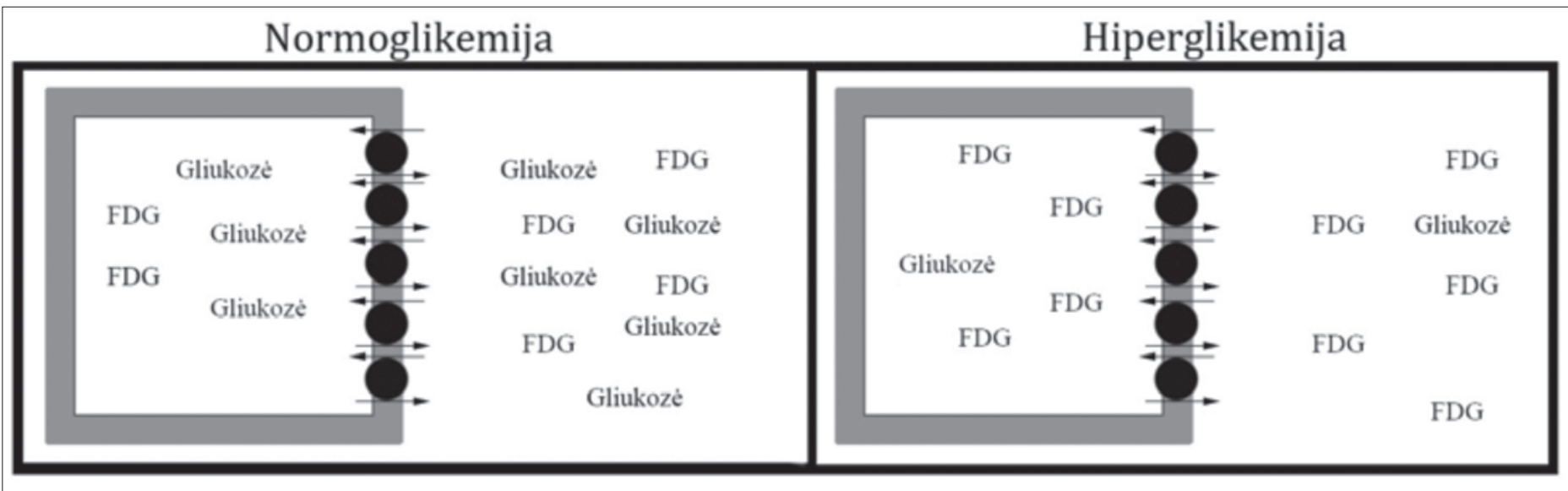

4 pav. FDG kaupimas esant normoglikemijai ir hiperglikemijai

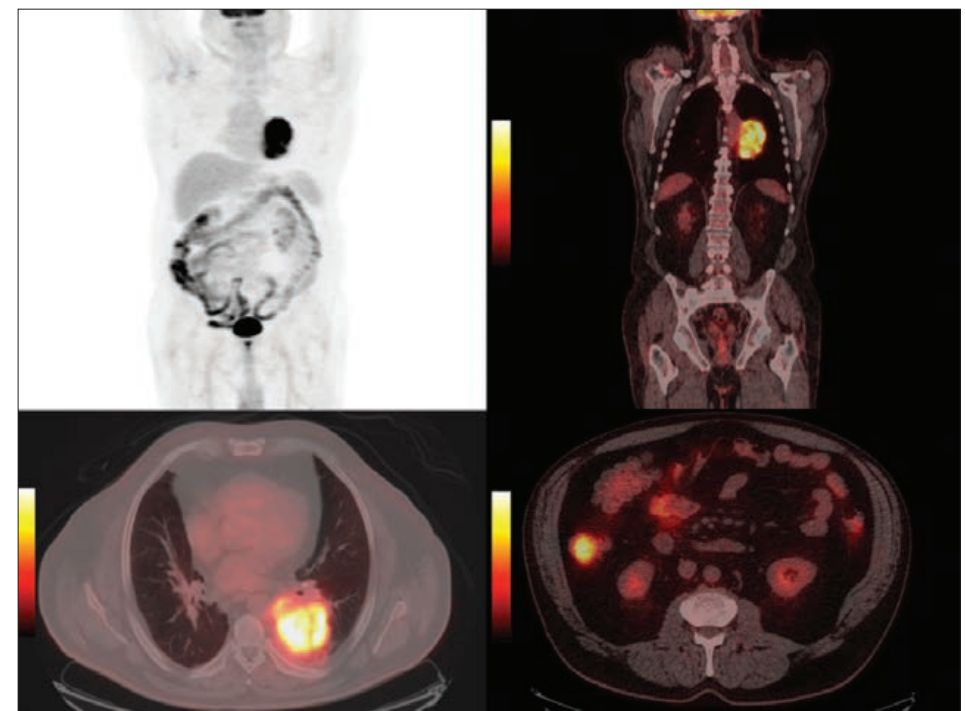

5 pav. PET-KT su ${ }^{18}$ F-FDG: navikas kairiajame plautyje, matyti padidèjęs FDG telkimasis žarnyne dèl metformino vartojimo

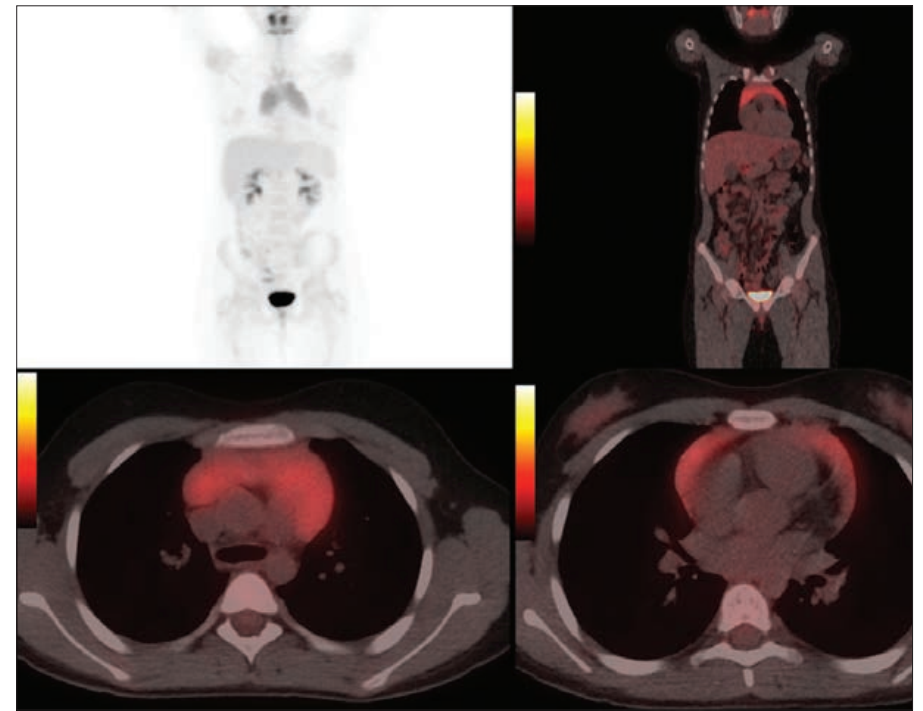

6 pav. PET-KT su ${ }^{18 F-F D G: ~ u z ̌ k r u ̄ c ̌ i o ~ l i a u k o s ~ h i p e r p l a z i j a ~ p o ~ c h e m o t e r a-~}$ pijos 
kiaušidèse, turi būti tiriamos nuodugniau. Tiriant antinksčius padidèjęs FDG telkimasis gali būti nustatomas ne tik piktybiniuose navikiniuose dariniuose, bet ir adenomų, angiolipomu, hiperplazijos atvejais, todèl svarbu rezultatus vertinti derinant ir morfologinius KT duomenis. Pasitaikantis padidèjęs fiziologinis FDG telkimasis antinksčiuose dažniausiai būna abipusis, nustatomas nesant morfologinių pokyčių KT vaizduose. Skydliaukèje didesnis FDG telkimasis galimas esant tiroiditui, Greivso ligai ar mazginei strumai, tačiau norint atskirti nuo piktybinio proceso reikia papildomų tyrimų. Padidèjęs židininis FDG telkimasis distalinèje stemplès dalyje gali būti dèl ezofagito, susijęs su Bareto stemple. Plonųjų žarnų projekcijoje klaidingai teigiamus padidejusio telkimosi židinius gali imituoti persidengiančios žarnų kilpos.

Atskira grupè atvejų, kai galimos pokyčių interpretavimo klaidos, yra onkologinių ligų atsako ì gydymą vertinimas. Dèl chemoterapijos dažna užkrūčio liaukos hiperplazija (vaikų ir paauglių fiziologinè) sąlygoja ryškų FDG telkimąsi priekiniame tarpuplautyje (6 pav.). Dèl neutropenijos gydymui vartojamo granuliocitu kolonijas stimuliuojančio faktoriaus poveikio galimas padidejęs FDG telkimasis kaulų čiulpuose. Spindulinio gydymo sukeltų komplikacijų (pospindulinio pulmonito, ezofagito, žarnų pažeidimo, poradiacinè kaulų nekrozè ir lūžiai) zonose padidèjęs telkimasis taip pat gali būti interpretuojamas klaidingai. Padidejusio FDG telkimosi židiniai, sąlygoti uždegimo ar reparacijos procesų, gali būti klaidingai interpretuojami kaip navikiniai ir po pleurodezès ar dèl suaktyvejjusių osteoblastų gyjant metastazėms kauluose.

Uždegimo ligos - dar viena galimo klaidingų PET rezultatų grupė [27-29]. Uždegimo procesuose dalyvauja neutrofilai ir suaktyveję makrofagai, kuriuose, kaip ir navikiniuose audiniuose, GLUT-1 ir GLUT-3 nešiklių aktyvumas yra padidejęs [30]. Dèl šios priežasties uždegimo židiniuose ir šalia esančiuose limfmazgiuose telkiasi FDG. Tai labai svarbu vertinant navikų išplitimą, metastazavimą i limfmazgius. Klaidingai teigiamus PET rezultatus gali sąlygoti bet kokia uždegimo liga: plaučių uždegimas, granuliominès ligos (sarkoidozè, tuberkuliozè, grybelinès granuliomos), vaskulitai ir kitos (5 lentelè). PET su ${ }^{18} \mathrm{~F}-$ FDG tyrimo specifiškumas yra gerokai mažesnis regionuose, kuriuose paplitusios granuliominès ligos [31]. Tai aktualu ir Lietuvoje, kur sergančiu tuberkulioze skaičius yra didelis. Pasaulio sveikatos organizacijos (PSO) duomenimis, 2013 metais tuberkuliozès paplitimas Lietuvoje siekè 85 atvejus 100 tūkst gyventojų [32].

\section{KLAIDINGAI NEIGIAMI PET REZULTATAI}

Nors PET su FDG yra pripažintas tyrimo metodas onkologijoje, tačiau net ir esant piktybiniams navikams galima nefiksuoti FDG telkimosi. Tai gali lemti naviko morfologija: kai kuriais adenokarcinomos atvejais bei esant karcinoidui, navikai esant daug mucino, kai kurios blogai FDG kaupiančios sarkomos, limfomos, smegenų navikai. Neigiami rezultatai galimi gerai diferencijuotuc šlapimo ir ly-
5 lentelè. Galimų klaidingai teigiamų PET-FDG rezultatų priežastys

\begin{tabular}{|c|c|}
\hline Uždegimo procesai & Gerybiniai navikai \\
\hline $\begin{array}{l}\text { Uždegimas, infekcijos, hemato- } \\
\text { mos po chirurginių procedūrų, } \\
\text { injekcijų, traumų, biopsijos vieta }\end{array}$ & $\begin{array}{l}\text { Adenomos (antinksčių, hipofi- } \\
\text { zès, kiaušidžių cistinè, skydliau- } \\
\text { kès folikulinè) }\end{array}$ \\
\hline Pokyčiai po spindulinio gydymo & $\begin{array}{l}\text { Storosios žarnos polipai ar } \\
\text { adenomos }\end{array}$ \\
\hline Pokyčiai po chemoterepijos & Seilių liaukų navikai \\
\hline $\begin{array}{l}\text { Uždegimo ligos, ypač granulio- } \\
\text { miniai procesai (pvz.: sarkoi- } \\
\text { dozè, grybinės, mikobakterinės } \\
\text { infekcijos) }\end{array}$ & Lejomioma \\
\hline Stomų, drenų vietos & Aneurizminè kaulo cista \\
\hline Tiroiditas & Stambiųjų ląstelių navikas \\
\hline $\begin{array}{l}\text { Ezofagitas, gastritas, žarnyno } \\
\text { uždegimo liga }\end{array}$ & Hiperplazija ir displacija \\
\hline $\begin{array}{l}\text { Üminis ar lètinis (dažniausiai) } \\
\text { pankreatitas }\end{array}$ & Gveivso liga \\
\hline $\begin{array}{l}\text { Üminis cholangitas ar chole- } \\
\text { cistitas }\end{array}$ & Kušingo liga \\
\hline $\begin{array}{l}\text { Osteomielitas, neseni lūžiai, } \\
\text { sąnarių protezai }\end{array}$ & Kaulų čiulpų hiperplazija \\
\hline Limfadenitas & Pedžeto liga \\
\hline Išemija/priblokštasis miokardas & Fibrozinė diplazija \\
\hline
\end{tabular}

tinès sistemos, prostatos, neuroendokrininių navikų, hepatoceliulinès, skydliaukès karcinomų atvejais. Reikšmingos itakos rezultatams gali turèti naviko nekrozė - fiksuojamas tik nežymus netolygus telkimasis gali būti vertinamas kaip nespecifinis. Dèl mažo dydžio ir kvėpavimo judesių smulkūs $(<8 \mathrm{~mm})$ ir palei pleurą esantys navikiniai dariniai gali būti klaidingai palaikyti metaboliškai neaktyviais.

\section{RADIACINE் SAUGA}

PET-KT tyrimo metu pacientai yra veikiami kombinuotos spinduliuotès, kurią sudaro RPF radioaktyvaus izotopo sąlygota spinduliuotė ir apšvita dèl tyrimo KT dalies. Pastaraisiais metais visame pasaulyje pabrèžiama medicininès apšvitos didejjimo ir su ja susijusios vẻžio rizikos augimo tendencija, analizuojami poveikiai skirtingoms pacientú grupèms, ieškoma būdų apšvitai mažinti. Atliekant viso kūno PET-KT su ${ }^{18} \mathrm{~F}-\mathrm{FDG}$, suaugusiesiems sušvirkščiama 350-740 MBq radioaktyviosios medžiagos, kuri šlapimo pūslèje gali sąlygoti $0,019 \mathrm{mSv} / \mathrm{MBq}$ efektinę dozę. Vaikams sušvirkštus $5,18-7,4 \mathrm{MBq} / \mathrm{kg}$, didžiausia šlapimo pūslès apšvita siekia 0,32 $\mathrm{mGy} / \mathrm{MBq}$, kas sudaro iki 0,05mSv/MBq (54-81 proc. sudaro KT apšvita) [24, 33, 34]. Taigi tyrimo metu paciento gaunama efektinè dozè gali siekti 5-80 mSv. Apšvitos sukeliama vėžio rizika proporcinga dozei ir siejama su dozès nulemtaisiais bei atsitiktiniais efektais, kuriems būdingas latentinis periodas. Reikia pažymèti, jog visų atsitiktinių poveikių sukeliama véžio rizika sumuojasi, kas labai svarbu atliekant tokios didelès apšvitos tyrimus jauniems pacientams. Pavyzdžiui, vieno PET-KT su ${ }^{18}$ F-FDG tyrimo metu gauta apšvita 20 metú amžiaus moteriai sukelia $0,231-0,514$ proc. (vyrui - 
0,163-0,323 proc.) riziką, kad pacientè mirs nuo apšvitos sukelto vèžio [34]. Taigi svarstant PET-KT tikslingumą reikètų nepamiršti ir jonizuojančiosios spinduliuotès poveikio bei laikytis ALARA (angl. As Low As Reasonably Achievable) principu.

\section{APIBENDRINIMAS}

Galimybė klinikinèje praktikoje remtis ir Lietuvoje prieinama viena naujausių vaizdinių-fiziologinių tyrimų metodikų PET-FDG neabejotinai praplečia diagnostinių tyrimų spektrą. Efektyvus PET-KT panaudojimas gali keisti ligos vadybą, tačiau nepakeičia kitų radiologinių, instrumentinių ir histologinio tyrimo metodų ir priklauso nuo visu specialistu gebejimo dirbti komandoje. Vertinant PET su ${ }^{18} \mathrm{~F}$-FDG galimybes, svarbu nepamiršti ir tyrimo ribotumo, kurị lemia tyrimo principai - tai iš dalies, bet reikšmingai gali paveikti tyrimo rezultatu vertinimą.

Apibendrinant svarbu pabrèžti klinikinių bei anamnezès duomenų ir paciento paruošimo tyrimui svarbą norint tinkamai atlikti tyrimą ir įvertinti jo rezultatus. Taigi PET tyrimų siunčiančių ir juos atliekančių gydytojų bei pacientų ar jų atstovų bendradarbiavimas yra svarbi kokybiško PET FDG tyrimo atlikimo ir tinkamo duomenų ịvertinimo bei pokyčių interpretavimo sąlyga.

\section{POSSITRON EMISSION TOMOGRAPHY - WHAT IS IMPORTANT TO REMEMBER}

\section{LAIMA TAMKEVIČIÜTÉ, JURGITA ZAVECKIENĖ, NEMIRA JURKIENÉ LUHS MA CLINIC OF RADIOLOGY}

Keywords: PET, ${ }^{18} \mathrm{~F}-\mathrm{FDG}$, evaluation.

Summary. Possitron emission tomography (PET) is still new in Lituania non-invasive nuclear imaging technique. PET scan provide information about metabolic activity of tissue in vivo, in contrast to other imaging modalities showing its morphology. There are a lot of physiological conditions and benign processes that can induce the metabolism of glucose and reduce the specificity of the ${ }^{18} \mathrm{~F}-\mathrm{FDG}$ PET. This is the reason why the anamnesis and clinical data are essential for the evaluation of the PET scans. The diagnostic value also depends on

appropriate preparation of the patient. PET can change the management of the disease, but it can't replace other radiological, instrumental and histological examinations.

\section{LITERATŪRA}

1. Lin EC AA: PET and PET/CT A clinical Guide: Thieme Medical Publishers; 2009.

2. Jadvar, H, Parker, JA: Clinical PET and PET/CT. springer 2005.

3. Miele E, Spinelli GP, Tomao F, Zullo A, De Marinis F, Pasciuti G, Rossi L, Zoratto F, Tomao S: Positron Emission Tomography (PET) radiotracers in oncology--utility of ${ }^{18} \mathrm{~F}$-Fluoro-deoxy-glucose (FDG)-PET in the management of patients with non-small-cell lung cancer (NSCLC). J Exp Clin Cancer Res 2008, 27:52-9966-27-52.

4. The Royal College of Physicians and the Royal College or Radiologists: Evidencebased indications for the use of PET-CT in the UK 2013 vidence-based indications for the use of PET-CT in the UK 2013 London: RCP, RCR 2013.

5. Gambhir SS, Czernin J, Schwimmer J, Silverman DH, Coleman RE, Phelps ME: A tabulated summary of the FDG PET literature. J Nucl Med 2001, 42(5 Suppl):1S-93S.

6. Qu X, Huang X, Yan W, Wu L, Dai K: A meta-analysis of (1)(8)FDG-PET-CT,
(1)(8)FDG-PET, MRI and bone scintigraphy for diagnosis of bone metastases in patients with lung cancer. Eur J Radiol 2012, 81(5):1007-1015.

7. Dèl lietuvos respublikos sveikatos apsaugos ministro $2011 \mathrm{~m}$. Gegužès 9 d. Isakymo nr. V-449 dèl ligu ir būkliu, kurioms esant atliekami privalomojo sveikatos draudimo fondo biudžeto lèšomis finansuojami pozitronu emisijos tomografijos tyrimai su fluorodeoksigliukoze, ir šiu tyrimu atlikimo indikaciju sąrašo patvirtinimo" pakeitimo. Teises aktu registras 20140408 , nr. 2014-04314.

8. Gould MK, Maclean CC, Kuschner WG, Rydzak CE, Owens DK: Accuracy of positron emission tomography for diagnosis of pulmonary nodules and mass lesions: a meta-analysis. JAMA 2001, 285(7):914-924.

9. Sim YT, Goh YG, Dempsey MF, Han S, Poon FW: PET-CT evaluation of solitary pulmonary nodules: correlation with maximum standardized uptake value and pathology. Lung 2013, 191(6):625-632

10. Gould MK, Kuschner WG, Rydzak CE, Maclean CC, Demas AN, Shigemitsu H, Chan JK, Owens DK: Test performance of positron emission tomography and computed tomography for mediastinal staging in patients with non-smallcell lung cancer: a meta-analysis. Ann Intern Med 2003, 139(11):879-892.

11. Alongi F, Ragusa P, Montemaggi P, Bona CM: Combining independent studies of diagnostic fluorodeoxyglucose positron-emission tomography and computed tomography in mediastinal lymph node staging for non-small cell lung cancer. Tumori 2006, 92(4):327-333.

12. Warburg O, Wind F, Negelein E: The Metabolism of Tumors in the Body. J Gen Physiol 1927, 8(6):519-530.

13. Rempel A, Mathupala SP, Griffin CA, Hawkins AL, Pedersen PL: Glucose catabolism in cancer cells: amplification of the gene encoding type II hexokinase. Cancer Res 1996, 56(11):2468-2471

14. Rempel A, Mathupala SP, Perdersen PL: Glucose catabolism in cancer cells: regulation of the Type II hexokinase promoter by glucose and cyclic AMP. FEBS Lett 1996, 385(3):233-237.

15. Macheda ML, Rogers S, Best JD: Molecular and cellular regulation of glucose transporter (GLUT) proteins in cancer. J Cell Physiol 2005, 202(3):654-662.

16. Cronin P, Dwamena BA, Kelly AM, Carlos RC: Solitary pulmonary nodules: meta-analytic comparison of cross-sectional imaging modalities for diagnosis of malignancy. Radiology 2008, 246(3):772-782.

17. Shreve PD, Anzai Y, Wahl RL: Pitfalls in Oncologic Diagnosis with FDG PET Imaging: Physiologic and Benign Variants. Radiographics 1999, 19(1):61-77.

18. Gordon BA, Flanagan FL, Dehdashti F: Whole-body positron emission tomography: normal variations, pitfalls, and technical considerations. AJR Am J Roentgenol 1997, 169(6):1675-1680.

19. Abouzied MM, Crawford ES, Nabi HA: ${ }^{18} \mathrm{~F}-\mathrm{FDG}$ imaging: pitfalls and artifacts J Nucl Med Technol 2005, 33(3):145-55; quiz 162-3.

20. Tan LT, Ong KL: Semi-quantitative measurements of normal organs with variable metabolic activity on FDG PET imaging. Ann Acad Med Singapore 2004, 33(2):183-185.

21. Long NM, Smith CS: Causes and imaging features of false positives and false negatives on F-PET/CT in oncologic imaging. Insights Imaging 2011, 2(6):679-698.

22. Culverwell AD, Scarsbrook AF, Chowdhury FU: False-positive uptake on 2-[(1)(8)F]-fluoro-2-deoxy-D-glucose (FDG) positron-emission tomography/ computed tomography (PET/CT) in oncological imaging. Clin Radiol 2011, 66(4):366-382.

23. Boellaard ,Ronald, Oâ€ ${ }^{\mathrm{T} M}$ Doherty ,MikeJ., Weber ,WolfgangA., Mottaghy ,FelixM., Lonsdale ,MarkusN., Stroobants ,SigridG., Oyen ,WimJ.G., Kotzerke Joerg, Hoekstra ,OttoS., Pruim ,Jan, Marsden ,PaulK., Tatsch ,Klaus, Hoekstra ,CornelineJ., Visser ,EricP., Arends ,Bertjan, Verzijlbergen ,FredJ., Zijlstra ,JoseeM., Comans ,EmileF.I., Lammertsma ,AdriaanA., Paans, AnneM., Willemsen ,AntoonT., Beyer ,Thomas, Bockisch ,Andreas, Schaefer-Prokop ,Cornelia, Delbeke ,Dominique, Baum ,RichardP., Chiti ,Arturo, Krause ,BerndJ.: FDG PET and PET/CT: EANM procedure guidelines for tumour PET imaging: version 1.0.

24. Delbeke D, Coleman RE, Guiberteau MJ, Brown ML, Royal HD, Siegel BA, Townsend DW, Berland LL, Parker JA, Hubner K, Stabin MG, Zubal G, Kachelriess $\mathrm{M}$, Cronin V, Holbrook S: Procedure guideline for tumor imaging with ${ }^{18}$ F-FDG PET/CT 1.0. J Nucl Med 2006, 47(5):885-895.

25. LSMU KK Radiologijos klinika. http://www.kaunoklinikos.lt/klinika26/Pasirengimas\%20PET info\%20pacientui.pdf

26. Surasi DS, Bhambhvani $P$, Baldwin JA, Almodovar SE, O'Malley JP: (1)(8) F-FDG PET and PET/CT patient preparation: a review of the literature. $J$ Nucl Med Technol 2014, 42(1):5-13.

27. An YS, Sun JS, Park KJ, Hwang SC, Park KJ, Sheen SS, Lee S, Lee KB, Yoon JK: Diagnostic performance of (18)F-FDG PET/CT for lymph node staging in patients with operable non-small-cell lung cancer and inflammatory lung disease. Lung 2008, 186(5):327-336.

28. Turkmen C, Sonmezoglu K, Toker A, Yilmazbayhan D, Dilege S, Halac M, Erelel M, Ece T, Mudun A: The additional value of FDG PET imaging for distinguishing $\mathrm{N} 0$ or $\mathrm{N} 1$ from N2 stage in preoperative staging of nonsmall cell lung cancer in region where the prevalence of inflammatory lung disease is high. Clin Nucl Med 2007, 32(8):607-612.

29. Bakheet SM, Saleem M, Powe J Al-Amro A, Larsson SG, Mahassin Z: F-18 fluorodeoxyglucose chest uptake in lung inflammation and infection. Clin Nucl Med 2000, 25(4):273-278. 